\title{
EPÄONNISTUMISEN POLIITTINEN IDEOLOGIA DISCO ELYSIUM -PELISSÄ
}

Tutkin tässä artikkelissa poliittisten ideologioiden esittämistä Disco Elysium -roolipelissä (Viro 2019) epäonnistumisen tematiikan kautta. Pohdin epäonnistumista sekä pelimekaniikassa että pelin kuvaamien ideologioiden sisällössä ja analysoin, miten Disco Elysiumin pelillisyys johtaa sen tuottamiin näkemyksiin ideologisesta ajattelusta. Keksityn siihen, miten pelissä kuvattu maailma avautuu pelaajalle tämän tekemien valintojen kautta ja miten sekä ideologioiden epäonnistumiset että epäonnistumisen ideologisuus on rakennettu maailmaan sisälle. Esitän, että roolipeligenrelle tyypilliset pelimekaaniset ratkaisut mahdollistavat ideologisen ajattelun simuloinnin pelin sisällä ja täten ideologioiden perusluonteiden paljastamisen pelin käyttämän huumorin avulla.

Lynkattu mies keinuu pihapuussa hotellin takana. Jännitteet lakkoilevien ahtaajien ja maailmaa hallitsevien suuryritysten välillä tihenevät. Rikkurit kerääntyvät telakan porteille vaatimaan pääsyä töihin, yksityisten turvallisuusfirmojen saapumista enteillään. Poliittisesti motivoitunutta murhaa selvittämään lähetetään kaksi poliisietsivää eri piireistä: Kim Kitsuragi, tunnollinen, rauhallinen ja ammattimainen työssään; sekä protagonisti - täydellinen ihmiskatastrofi, joka ensimmäisenä tekonaan juo itsensä niin tukevaan humalaan, ettei muista sen jäljiltä itseään, maailmaansa tai maailmankuvaansa. Roolipeli Disco Elysium (Viro 2019) alkaa pimeästä, kun pelaaja herää maailmaan, jota protagonisti ei tunnista. Revacholin kaupungin fiktiivisessä, dystooppisessa urbaanifantasiamaailmassa pelaaja etsii itseään keskellä kilpailevia poliittisia ideologioita ja kasvavia sosiaalisia jännitteitä. Kaiken yllä velloo nostalginen kaipaus diskoon - supertähtien optimistiseen aikaan, jolloin kaiken uskottiin olevan mahdollista. Nyt jäljellä on vain kaiken syövä krapula sekä Revachol - paikka, jossa Kim Kitsuragin mukaisesti "kaikki aatteet ja poliittiset suuntaukset ovat epäonnistuneet".

Epäonnistumisen tematiikka on syvällä Disco Elysiumin ytimessä. Se muodostaa myös tämän artikkelin keskeisen teeman. Kysyn, miten Disco Elysium rakentaa kuvaustaan poliittisista ideologioista epäonnistumisen kautta ja miten se huumorin avulla mahdollistaa pelaajan kanssakäymisen poliittisten 
aatteiden kanssa. Tämä on yksi tapa, jolla populaarikulttuuri ja politiikka limittyvät toisiinsa: populaarikulttuuri yhdistää kuluttajansa laajempiin poliittisiin ideologioihin (ks. esim. Street \& al. 2013, 19-23). Pelit mediamuotona tarjoavat ainutlaatuisen ympäristön poliittisten ajatusten käsittelyyn sääntöpohjaisen luonteensa johdosta. Ne tuottavat (poliittisen) ympäristön pelaajan toiminnan ympärille ja asettavat hänet suoraan vuorovaikutussuhteeseen sen kanssa (Bogost 2007; ks. myös Muriel \& Crawford 2018, 60-83).

Pelitutkimuksessa pelien poliittista luonnetta on avattu tutkimalla, miten pelit voivat joko vahvistaa tai kyseenalaistaa olemassa olevia ideologisia rakenteita, esimerkiksi identiteettien tai laajempien poliittisten suuntausten osalta (Bos 2018; Gray \& al. 2018; Taylor \& Voorhees 2018). Tässä artikkelissa keskityn epäonnistumiseen tämän prosessin osana. Epäonnistumisen tematiikka on luontainen tapa lähestyä Disco Elysiumia, koska se hallitsee sekä pelin sisältöä että sen tuotannon ja vastaanoton kontekstia laajemmin. Pelin kehittänyt virolainen indie-peliyhtiö ZA/UM kuvaili sitä tuotantoprosessin alkuvaiheessa peliksi "täydellisestä epäonnistumisesta. Lähes korjaamattomasta, kursailemattomasta epäonnistumisesta. Sekä ihmisenä että lainvalvojana" (ZA/UM 2016). Pelin tuotantoeetos sisälsi käskyn: "Ennen kaikkea - luo suunnattoman kunnianhimoisia ylärakenteita. Suuri epäonnistuminen on kymmenen kertaa parempi kuin pieni onnistuminen" (Kurvitz 2016). Peli on luotu mukautumaan pelaajan hölmöimpienkin toiveiden ympärille (Cox 2018), mutta samalla monen ensikosketus peliin oli kuolla sydänkohtaukseen poistumatta edes pelihahmon hotellihuoneesta (McDonald 2019). Pelin vastaanotossa kriitikot korostivat, ettei antoisin pelikokemus välttämättä synny tavoittelemalla täydellisyyttä, vaan antamalla pelihahmon epäonnistua ja nauttimalla joskus katastrofaalisistakin seurauksista (Arguello 2020). Yksi katsaus kutsui sitä "lumoavaksi oppitunniksi epäonnistumisesta" (Foong 2020).

Pelitutkimuksessa epäonnistumisen mahdollisuus on monesti nostettu määrittäväksi tekijäksi peleille mediamuotona. Pelien olemusta tutkinut Veli-Matti Karhulahti (2015, 16-17) on esimerkiksi nähnyt onnistumisen ja epäonnistumisen "emotionaalisina vastauksina videopelien muuttuviin olosuhteisiin". Samassa hengessä Jesper Juul $(2013,2)$ on kirjoittanut "epäonnistumisen paradoksista": ihmiset haluavat onnistua, mutta hakeutuvat kuitenkin pelaamaan videopelejä, vaikka ne pitävät sisällään epäonnistumisen mahdollisuuden. Pelit toimivat Juulin mukaan tasapainottelemalla erilaisten epäonnistumiskokemusten välillä: yhtäältä pelit tuottavat epäonnistumisia, jotka usein johtuvat jostain pelaajan vaillinaisuudesta, mutta toisaalta ne tarjoavat väylän käsitellä tätä epäonnistumista, koska pelit ovat viimekädessä keinotekoisia rakennelmia, joissa epäonnistumisella ei ole todellisia seuraamuksia (Juul 2013, 21).

Politiikan tutkimuksen kentällä nojaan Michael Freedenin työhön koskien poliittista ajattelua, jonka hän näkee monesti arkipäiväisissä ympäristöissä tapahtuvana toimintana. Freedenille $(2013,27-54)$ banaalitkin normatiiviset käsitykset yhteiskunnan järjestäytymisestä näyttäytyvät ideologisesti latautuneina. Ideologiat ovat täten tämän artikkelin kontekstissa ymmärrettävissä monenkirjavasti. Peli käsittelee monia perinteisiä -ismejä, kuten kommunismia, fasismia, liberalismia ja kapitalismia, jotka arkikielessä on ymmärretty ideologia-termin pääasialliseksi sisällöksi (Freeden 2019, 7). Näitä laajemmin näen kuitenkin ideologian poliittisesti määräytyvänä, normatiivisena kulttuurisena merkitysjärjestelmänä, jossa vaihtelevat arkipäiväiset kulttuuriset ilmiöt sulautetaan osaksi laajempaa, niille merkityksensä antavaa kokonaisuutta (ks. esim. Cresswell 1996, 14; Geertz 1973, 213-220; Robin 2018, 23). Mikäli pelit 
nähdään kulttuurisina merkitysjärjestelminä itsessään, kuten Frans Mäyrä $(2008,13-20)$ on ehdottanut, niin tällöin peli luo pelaamisen kautta merkityksiä kuvailemiensa ilmiöiden ympärille ja sitten kartoittaa nämä tuotetut merkitykset osaksi laajempia ideologisia järjestelmiä. Pelin kautta pohdin, mitä merkityksiä ideologian epäonnistumiselle annetaan, mitä epäonnistuminen tarkoittaa ideologian kuvatuille perusolettamuksille ja miten peli ilmentää ajatusta epäonnistumisen ideologiasta.

Olen analyysissäni kiinnostunut pelaajan toiminnan, kuvattujen ideologioiden ja taustalla rakentuvan roolipelimaailman keskinäisestä vuorovaikutuksesta. En siis tässä artikkelissa keskity varsinaisesti pelin juoneen, muutoin kuin siltä osin miten se kanavoi pelin maailmaan rakennettuja jännitteitä. Lähestymistapaani voi kuvailla kontekstualisoivaksi lähipeluuksi. Jonne Arjoranta $(2015,6)$ on kuvannut lähipeluuta tutkimustavaksi, jossa "pelaamalla peliä tarkkaavaisesti ja toistuvasti tutkija muuttaa itsensä tutkimusvälineeksi, joka luotaimen tavoin syöksyy pelin maailmaan ja kartoittaa sen tuntemattomia syvyyksiä". Lähipeluussa tutkija uppoutuu tutkimaansa peliin ja analysoi siitä löytämiään ilmiöitä. Kontekstuaalisen lähestymistapani (ks. esim. Hallila 2006, 23-24) myötä syvennän analyysiani suhteuttamalla havaintojani siihen, miten pelin kehittäjät ovat julkisesti kommentoineet omaa tuotantoprosessiaan, sekä siihen, miten peli vastaanotettiin kriitikoiden keskuudessa.

Tässä artikkelissa lähipeluuni koostuu kahdesta, erilaisten pelissä tehtyjen valintojen ohjaamasta läpipeluukerrasta. Koska peli muovautuu vahvasti pelaajan tekemiin valintoihin ja yhden pelikerran pituus lähenee helposti 30 tuntia kestoltaan, en esitä tässä artikkelissa totaalista näkemystä pelin kaikista mahdollisuuksista, vaan keskitän havaintoni näihin kahteen polkuun. Kontekstualisoivan tutkimusmateriaalini olen kerännyt kansainvälisestä, peleihin keskittyneestä verkkomediasta ja se sisältää arvioita, uutisointia sekä pidempiä analyyseja.

\section{Kaupungin sykettä ja kummia enteitä: Disco Elysium pelinä}

Disco Elysium on pelinä tarinavetoinen ja dialogikeskeinen - pelin kehittäjä on kehunut käsikirjoituksen olleen pituudeltaan yli miljoona sanaa (Chalk 2019). Tyyliltään se on humoristinen, joskaan sitä ei voitane kuvailla komediaksi. Eroa on korostanut Rami Mähkä $(2016,29)$ : komediassa huumori on ensisijaista, muutoin se on alisteista muille tarinankerronnan osa-alueille. Tämän on huomioinut myös pelin luoja, virolainen kirjailija Robert Kurvitz (s. 1984). Hän on kuvaillut pelin aloitusta videopeliversioksi komediaelokuvasta Dude, Where's My Car? (USA, 2000), jossa päähenkilöt heräävät krapula-aamuna vailla muistikuvia edellisillasta ja joutuvat selvittämään illan kulkua. Kurvitz toteaa kuitenkin, että pelin "humanitäärisen kunnianhimon" johdosta pelihahmon suhde alkoholiin ja huumausaineisiin ei voinut jäädä pelkäksi vitsiksi. Niistä tehtiin protagonistin yllä roikkuva kirous, jonka vaikutuksia hän joutuu pelin halki kohtaamaan (Nelson 2019). Huumori on pelissä täten kietoutunut sekä tarinallisten että "humanitääristen" impulssien ympärille.

Peliyhtiö ZA/UM (2020) mainostaa peliä "uskollisimpana koskaan yritettynä videopelimukaelmana pöytäroolipeleistä". William White et al. (2018, 65-66) ovat kuvailleet pöytäroolipelejä performatiiviseksi tekstuaalisen tuotannon muodoksi, jossa lopullinen peli muotoutuu pelaamishetkellä usean eri toimijan yhteisvaikutuksessa. Disco Elysiumin ambitiona on tuottaa pelikokemus, joka rakentuu yhtä lailla orgaanisen oloisesti pelaajan ympärille. 
Myös tietokoneroolipeligenrelle ominaista on ollut korostaa pelaajan vapautta ja hänen toimintansa merkityksellisyyttä. Roolipeleille keskeistä on antaa pelaajalle mahdollisuus tehdä valintoja ja juurruttaa nämä valinnat sitten osaksi moraalista järjestelmää, jonka sisällä ne saavat lopulta merkityksensä (Maier 2019, 65-66, 71-72; Sicart 2009). Samalla Jon Adams (2019, 185-186) on esittänyt, että roolipelien suosion taustalla voisi olla se, miten ne tuovat takanaan vaikuttavat algoritmit näkyväksi osaksi pelikokemusta.

Disco Elysiumissa tämä näkyy siinä, miten pelaajan pelihahmolleen valitsemat kyvyt ovat läsnä pelissä. Painotetut kyvyt tuottavat jatkuvasti havaintoja pelaajaa ympäröivästä maailmasta muokaten sitä, miten hän ympäristönsä hahmottaa. Käydyn keskustelun lomassa vaikkapa hahmon empatiakyky voi ilmoittaa onnistuneesta taustalla tehdystä heitosta, jonka myötä se paljastaa lisätietoa vastapuolen tunnemaailmasta. Pelin kuluessa pelaaja kohtaa haasteita, joiden onnistumisprosentti on laskettu vertaamalla halutun toimen vaikeusastetta sen vaatiman kyvyn tasoon ja lisäämällä mukaan erinäiset ympäristöstä kumpuavat muuttujat. Lopputulos ilmaistaan pelaajalle haasteen onnistumisprosenttina.

Peli alkaa roolipeligenrelle tyypilliseen tapaan hahmon luonnista. Pelaaja voi valita etsivälleen yhden kolmesta tarjotusta arkkityypistä (thinker, sensitive tai physical), mutta peli tarjoaa myös mahdollisuuden oman kykykokoelman luomiseen. Tällöin pelaaja jakaa pisteitä neljään eri ominaisuuteen, älykkyyteen, psyykeen, fyysiseen voimaan ja motoriikkaan. Jokainen ominaisuus sisältää kuusi eri taitoa, joista yhden pelaaja valitsee nimikkokyvykseen. Pelin kuluessa pelaaja kerryttää kokemuspisteitä, joita hän voi jakaa joko kehittääkseen kykyjään tai avatakseen lisää tilaa "ajatuskabinettiinsa": oppiessaan lisää asioita pelin maailmasta voi pelaaja päättää keskittyä johonkin ajatukseen ja omaksua sen osaksi persoonaansa, mikä puolestaan vaikuttaa hänen käyttäytymiseensä maailmassa vaihtelevin tavoin. Esimerkiksi kommunistisen aatteen omaksunut etsivä voi keskustella työväen kanssa luokkasorrosta. Ajatuksia on pelissä lukuisia ja ne voivat vaihdella suurista aatteista pieneen triviaan.

Pelin sisältämät kyvyt ovat yhtä lailla moninaisia. Osa on sisällöltään selkeitä, kuten älykkyyden alle kuuluva Logiikka ${ }^{1}$ tai tunneälyyn sisältyvä Empatia. Muut ovat epämääräisempiä, kuten fyysisyyden alle nivoutuva Shivers, jonka avulla etsivä kykenee film noir -hengessä aistimaan kaupungin sykkeen ja virittäytymään sen taajuudelle, tai psyykeen kuuluva Inland Empire, joka sisältää uskon yliluonnolliseen ja enteisiin ja mahdollistaa etsivän käymään (kuvitteellisia) keskusteluita esineiden kanssa. Jokainen kyky sisältää humoristisen kuvauksen sekä ehdotuksen, millaiselle hahmoarkkityypille se soveltuu.

Pelaajan kehittämillä kyvyillä on merkittävä rooli siinä, millaiseksi pelikokemus muodostuu. Sherlock Holmes -henkistä etsivää kaipaavat voivat painottaa Logiikkaa, Havainnointikykyä ja Visuaalista hahmottamista ja tehdä monimutkaisia päätelmiä ympäristöstä. Inland Empire -kyvyn ja pelissä tehtävien valintojen kautta etsivän on mahdollista uskotella itselleen olevansa osa paranormaalia iskujoukkoa, joka tutkii yliluonnollisia tapauksia, ja edetä tutkimuksessa enteiden ja aavistusten avulla. Jokainen kyky muodostaa oman persoonallisen henkilöhahmonsa, joka puhuu pelaajalle ja kommentoi hänen tekemisiään. Joskus kyvyt kinastelevat keskenään, kun niiden keskinäiset tulkinnat tilanteesta risteävät, tai yksi yrittää ohjata pelaajaa toiselle epäsuotuisaan suuntaan. Mitä enemmän pelaaja kykyyn panostaa, sitä vahvemmin se on keskusteluissa läsnä.

Kutsun tässä artikkelissa käyttämiäni hahmoja nimillä Etsivä1 ja Etsivä2. Etsivä1 (nimikkokyky: Shivers) on kovaksi keitetty, vahvimman oikeuteen
1 Käytän kyvyistä suomenkielistä nimeä silloin kun se on yksioikoisesti käännettävissä, mutta erikoisempien kykynimien kohdalla olen päätynyt käyttämään alkukielistä termiä. Kirjoitan kykyjen nimet isolla alkukirjaimella, koska kyse on myös hahmosta pelin sisällä. 
uskova supertähtipoliisi, joka on yltiöindividualistinen ja samalla rasistinen, misogyyninen ja taipuvainen fasismiin. Etsivä2 (nimikkokyky: Inland Empire) uskoo yliluonnolliseen ja tulevaan maailmanloppuun, katuu pelin alkua edeltävää elämäänsä ja kallistuu ideologisesti kommunismiin, joskaan ei usko todellisen muutoksen olevan mahdollista. Käyttämäni kuvaukset ovat yhdistelmä kutakin pelikertaa edeltävästä hahmokonseptista, jonka pohjalta pyrin pelihahmoani ohjaamaan, sekä pelikerran aikana pelin tarjoamien tapahtumien pohjalta niihin tekemistäni muutoksista. Tämä noudattelee roolipeleille klassista pelitapaa, jossa pelaaja seuraa hahmolleen kehittämiä sisäisiä sääntöjä ja periaatteita valintoja tehdessään (ks. esim. Heliö 2004, 70-71; Montola 2012, 41-44). Osa tekemistäni ennakkopäätöksistä osoittautui tutkimusasetelmani kannalta hedelmällisemmäksi kuin toiset.

\section{Epäonnistumisesta elämässä ja ideologiassa}

Tarinallisesti Disco Elysium alkaa aallonpohjalta. Humalaputken jäljiltä pelihahmo ei muista itseään tai maailmaansa. Hänen henkilökohtaiset epäonnistumisensa taustalla kummittelevasta avioerosta hänen humalaisiin toilailuihinsa kytkeytyvät pelin laajempaan epäonnistumisen tematiikkaan. Kommunistinen vallankumous (isänään ideologi Kras Mazov) on tullut ja mennyt; sen on korvannut ultraliberalistinen, ulkomaalaisten kauppaintressien ajama kapitalismi sekä Revacholia etäältä hallitsevan maailmanhallituksen, Koalition, kannattama moralismi. Pelin keskeinen ideologinen jännite on kapitalismin häviäjien (telakkatyöläisten) ja voittajien (suuryhtiöt) välillä. Moralismi on pelin status quo -tilaa ylläpitävä, sentristinen näkemys, joka kieltäytyy ottamasta kantaa maailman suuriin kysymyksiin. Sen kantava aate, Kingdom of Conscience, kuvailee ideologiaa seuraavasti:

Moralisteilla ei varsinaisesti ole uskomuksia. Joskus he törmäävät sellaiseen, kuin matolle unohdettuun lapsen leluun. Lelu pitää korjata talteen välittömästi. Ja lasta toruttava. Sentrismi ei ole muutosta - ei edes vähittäistä muutosta. Se on hallintaa. Itsesi sekä maailman. Harjoita sitä. Katso ylös taivaisiin, kohti Koalition ilmalaivojen synkkiä varjoja. Kysy itseltäsi: onko moralismissa jotain pahantahtoista? Ja sitten vastaa: ei. Jumala on taivaassaan. Kaikki on normaalia maan päällä.

Kantaa ottamattomuus näyttäytyy pelissä itsessään ideologisena. Se on ideologiaa vailla aatetta tai uskomuksia, puhdasta pyrkimystä kohti (itse) hallintaa vailla toivetta, että maailmaa olisi mahdollista saattaa paremmaksi. Se on nykyisyyden dominanssia suhteessa sekä paettuun menneisyyteen että pelättyyn tulevaisuuteen. Moralismin epävirallinen motto onkin pelissä, "hetkeksi, oli toivo". Se on samanaikaisesti hallitsevan luokan kietoutumista omaan arvovaltaansa, lamaannuttavaa pelkoa epäonnistumisesta ja sokeutta maailmaa hallitseville vääryyksille.

Michael Freeden on huomauttanut, että politiikantutkimus on usein ylikorostanut ideologioiden epäonnistumista suhteessa muuhun poliittiseen ajatteluun. Ideologioita ei ole nähty tarpeeksi irtaantuneiksi poliittisesta prosessista, jotta ne kykenisivät huomioimaan omia puutteitaan (Freeden 2009a, 1). Tässä kontekstissa Freeden (2009a, 2) on nähnyt ideologiat "julkisen poliittisen kielen hallintaa koskevina toimintaorientoituneina kilpailuina, joiden tarkoituksena on puolustaa tai muuttaa olemassa olevia poliittisia järjestyksiä". Epäonnistuminen tapahtuu, kun erilaiset kuvailevat käsitykset 
yhteiskuntajärjestyksestä eivät saavuta normatiivista statusta, eli toisin sanoen ne eivät kykene tuottamaan itsestään hallinnoivaa näkemystä yhteiskunnasta (Freeden 2009b, 142). Muutoin ideologia voi epäonnistua, kun se menettää uskonsa omiin perusoletuksiinsa tai johtaa kannattelemansa poliittisen järjestelmän romahdukseen (Freeden 2009a, 2). Disco Elysiumin Revachol on tällä perusteella epäonnistuneiden ideologioiden leikkikenttä. Yksikään ideologioista ei ole onnistunut nousemaan hallitsevaksi näkemykseksi. Eri ideologioita edustavat hahmot ovat pelissä toistuvasti joko korruptoituneita, ideaalinsa menettäneitä tai todellisuudesta vieraantuneita.

Freeden on kuvannut ideologioiden toimintaperiaatteita performatiivisina: ne tekevät asioita puhumalla niistä. Täten niiden onnistuminen ja epäonnistuminen määrittyvät suhteessa siihen, miten ne kykenevät ottamaan haltuunsa kohdettaan määrittelevän kielen (Freeden 2009a, 5). Epäonnistuminen onkin ollut usein tabu poliittisten ajattelijoiden parissa, koska pelkän epäonnistumisen mahdollisuuden on nähty syövän ideologian tai poliittisen teorian todistusvoimaa (Freeden 2009b, 144).

Disco Elysium toteuttaa tätä ideologian performatiivisuutta pelihahmon ajattelua kuvatessaan. Mitä selkeämmin pelihahmo sitoutuu ideologiaan esittämällä sen perusnäkemyksiä, sitä vahvemmin alkaa maailma näyttäytyä hänelle sen suodattamana. Ideologian olettamukset ilmaantuvat osaksi pelihahmon arkikieltä. Esimerkiksi sama sivutehtävä kahden toisiinsa ihastuneen sivuhahmon saattamiseksi yhteen voi feministiksi julistautuneen Etsivä2:n kohdalla johtaa saarnaan esimiesten ja alaisten välisten seurustelusuhteiden ongelmallisista valtapositioista, kun taas misogyynisen Etsivä1:n tapauksessa tilanne päätyy vulgaariin vuodatukseen naisten kevytkenkäisyydestä (kuva 1).

Yksi klassinen pelitutkimuksen esitys pelien erityispiirteistä on ajatus simulaatiosta. Tämän näkemyksen mukaan siinä missä muut mediamuodot

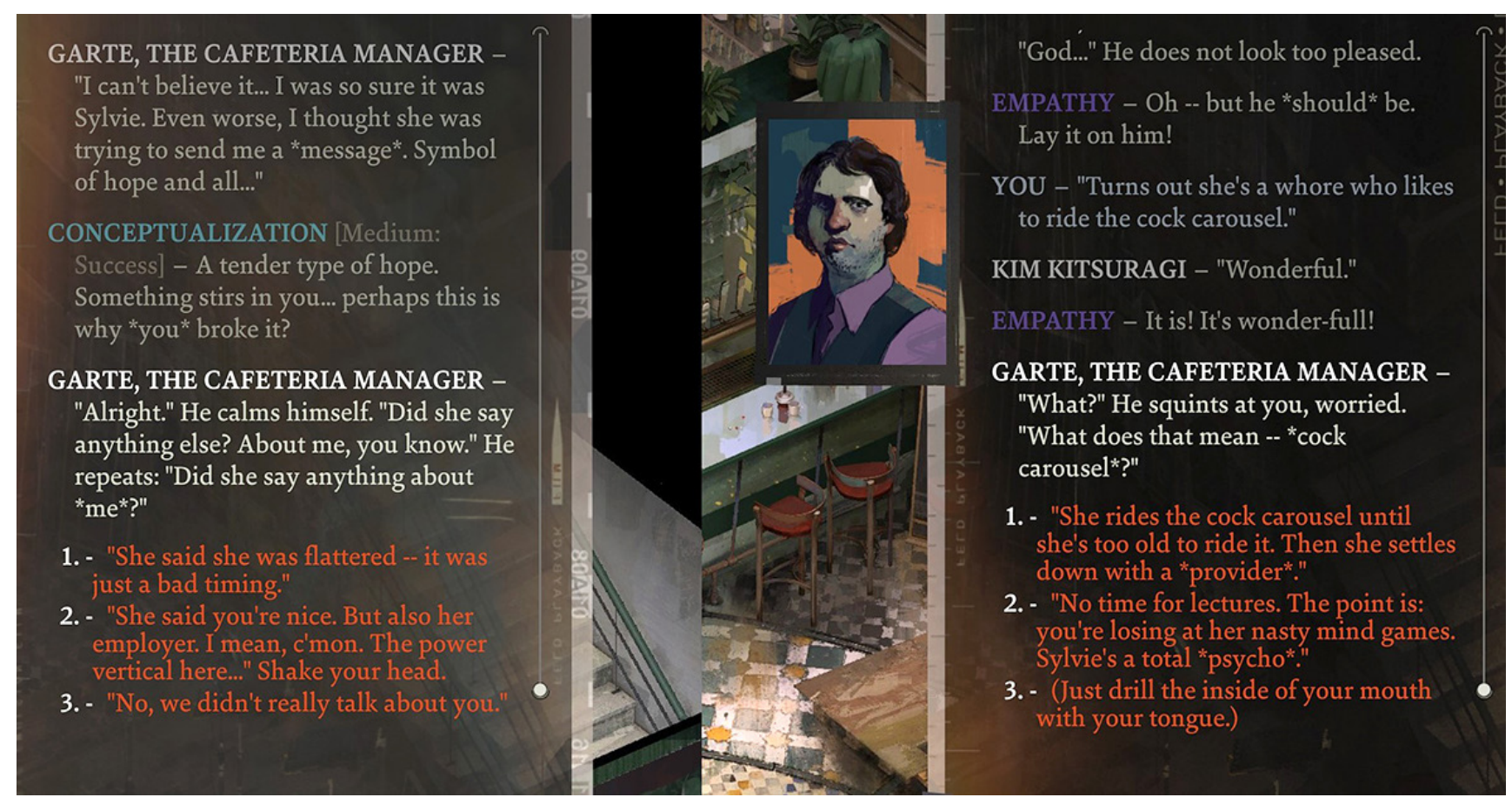

Kuva 1. Sama kohtaus molempien hahmoprofilieni kautta suodattuneena. Numeroidut, punaisella fontilla kirjoitetut tekstit ovat hahmoilleni tarjottuja vastausvaihtoehtoja. Niiden yllä näkyy aikaisempi keskustelu. 
tuottavat representaatiota ilmiöistä, pelit sen sijaan simuloivat niitä, eli uudelleen tuottavat niitä tiettyjen periaatteiden mukaisesti, pelaajan toiminnan ympärille kietoutuen (Aarseth 2007; Frasca 2003, 222-224). Marie-Laure Ryan (2006, 188-189) on johtanut tästä kuvauksen peleistä "tarinakoneina", jotka pelikokemuksen aikana tuottavat tarinan peliin rakennettujen periaatteiden mukaisesti. Kuten Veli-Matti Karhulahti $(2015,49-51)$ on huomauttanut, teoria pitää lähtökohtaisesti sisällään oletuksen, että peli tuottaa versioita ilmiöistä, joilla on lähde pelin ulkopuolella.

Disco Elysium on hahmotettavissa tämän simulaatioperiaatteen mukaisesti ideologista ajattelua tuottavana koneena. Pelin taustalta löytyvä maailma ja sen tarinaa hallitsevat jännitteet muodostavat pelin luurangon, jonka ympärille peli generoi lihaa simuloimalla pelihahmon omaksumia ideologisia aatteita. Pelaajan kohtaamat tilanteet voivat toistua eri pelikertojen välillä, mutta ne kulttuuriset merkitykset, joita tapahtumien ympärille rakennetaan, vaihtelevat pelihahmon seuraamaan ideologiseen raamistoon pohjaten. Täten peli on erinomainen esimerkki Ian Bogostin (2007, 2-4) kuvailemasta proseduraalisesta retoriikasta, jossa pelit tuottavat algoritmisen rakenteensa pohjalta vaikutuksellisia näkemyksiä esittämistään ilmiöistä.

\section{Moraalit ja manifestit}

Pelin proseduraalinen retoriikka pohjautuu sen aikaisemmin esittelemääni "humanitääriseen kunnianhimoon". Esitän, että epäonnistumisen tematiikkansa pohjalta Disco Elysiumin voi nähdä pyrkimyksenä kohti manifestitaidetta, siten kuin termin on kuvaillut avantgarde-tutkija Martin Puchner. Kyse on taiteesta, joka on "luotu manifestin kuvaksi; aggressiivista pikemminkin kuin sisäänpäin kääntynyttä; huutavaa pikemminkin kuin pidättäytyvää; kollektiivista pikemminkin kuin individualistista" (Puchner 2006, 6). Näkemykseni saa tukea siitä, miten Kurvitz on kuvaillut ZA/UM:n olevan pikemminkin dadaismiin tai fluxukseen verrattava kulttuurinen liike kuin tavanomainen pelistudio (Nelson 2019). Studion nimi viittaa venäläisen futuristisen runouden termiin zaum, pohjanaan adjektiivi zaumnyi, eli käsityskyvyn ylittävä, liian monimutkainen ymmärrettäväksi (Janecek 2012, 1552).

Tämä näkyy myös pelin ympärille luodussa mediakuvastossa. Vastaanottaessaan palkintoa vuoden 2019 Game Awards -tapahtumassa ZA/UM:n edustaja kiitti muun muassa Karl Marxia ja Friedrich Engelsiä (Jackson 2019). Lähestyessään yhdysvaltalaisen vasemmistopodcastin Chapo Trap Housen juontajia ääninäyttelijöiksi peliin (yhteistyökuvio, joka toteutuikin) ZA/UM esittäytyi saatekirjeessään "viimeisinä elävinä neuvostovideopelikehittäjinä" (McCarthy 2019). Vuodelle 2020 enteili Kurvitz julkaistavaksi kirjallista manifestia ZA/UM:n periaatteista (Nelson 2019), mutta kirjoitushetkellä sitä ei vielä ole ilmaantunut. Peli on luotu poliittiseen ja taiteelliseen eetokseen pohjaten, tarkoituksenaan käsitellä ja kommunikoida ajatuksia maailmantilasta ja ideologioiden kriisistä.

Raskaat teemat ovat Jonas Linderothin ja Torill Elvira Mortensenin $(2015,4)$ mukaan historiallisesti jopa määrittäneet digitaalisen pelaamisen kuvaa kulttuurissa. Absurdin humoristisesta olemuksestaan huolimatta Disco Elysium painii raskaiden ilmiöiden parissa. Kun pelaaja poimii herättyään solmionsa kattotuulettimesta (teko, joka voi epäonnistuessaan johtaa sydänkohtaukseen ja kuolemaan), peli vihjaa, että hän on sen sinne edellisenä yönä ripustanut toimimaan hirttosilmukkana. Pyrkiessään selvittämään omaa identiteettiään pelihahmo kohtaa lähinnä pilkkaa, sääliä tai halveksuntaa. 
Pelihahmon ankea ja humalankatkuiseen umpikujaan johtanut menneisyys tuskaisine avioeroineen roikkuu raskaana hänen yllään, ja pelaaja voi omilla valinnoillaan tehdä hahmostaan halutessaan rasistisen ja misogyynisen ihmishirviön, joka syyttää henkilökohtaisesta ja koko Revacholin kaupungin alennustilasta ulkomaalaisia, naisia ja kaikkia muita, jotka ovat sotkeneet maailman "luonnollisen" järjestyksen. Tässä peli noudattelee roolipeligenrelle tyypillistä moraalijärjestelmää, jossa pelaajalle tarjotaan mahdollisuus halutessaan pelata "pahaa" hahmoa. Näihin peleihin sisältyy eettinen dynamiikka, jossa osa pelaajan nautinnosta syntyy moraalisista valinnoista (Mortensen 2015, 157-159). Tällaisten pelien hallitseva eettinen periaate on, että ne tuottavat pelaajan valintojen seuraamukset osaksi pelikokemusta ja täten pakottavat hänet kohtamaan tekojensa vaikutukset (Sicart 2009, 107-109).

Disco Elysiumissa moraalijärjestelmä on manifestitaiteen hengessä pikemminkin kollektiivinen kuin yksilöllinen. Peli toistuvasti vetää pelihahmon yksittäisiä tekoja osaksi laajempia ideologisia rakenteita. Jos pelaaja toimii omaa etuaan ajavasti, peli ehdottaa, että hän saattaa olla kapitalisti. Jos hän toimii rasistisesti tai misogyynisesti, peli ehdottaa fasismia. Täten binäärisen hyvä-paha-järjestelmän sijasta Disco Elysiumin eettinen universumi koostuu ideologioiden verkostoista, joissa yksittäiset teot ja ajatukset juontuvat toistuvasti osaksi laajempia struktuureja.

Puchner (2006, 2-6) esittää, että manifestit eivät ole vain poliittisia dokumentteja, vaan niillä on oma poetiikkansa, ja tästä vastavuoroisesti seuraten tietyt poliittisen taiteen lajit ovat nähtävissä yhtenä poliittisen manifestin muotona. Manifestit luovat performatiivisesti maailmankuvaansa ja käsityksiään "moderniteetin fantasioista, toiveista, aspiraatioista ja puutteista" (Puchner 2006, 7). Jäljittäessään manifestitaidetta venäläiseen futurismiin jonka parista peliyhtiön nimessään käyttämä termi zaum nousee - Puchner $(2006,98)$ on kuvaillut niissä käytettyjä tekniikoita "jokapäiväisen kielen murtamisena pieniin yksiköihin vain kasatakseen ne uudelleen ainutlaatuisin ja yllättävin tavoin".

Samalla tavoin Disco Elysium purkaa yksittäisiä pelistä löytyviä tekoja ja ajatuksia niiden perustavanlaatuisiin komponentteihin ja kasaa ne sitten kohti kokonaisuuksia, jotka eivät vain myötäile pelin kuvaamia ideologioita, vaan paljastavat jotain niiden perusluonteesta. Samalla roolipeligenrestä tutut pelimekaaniset ratkaisut kykyjärjestelmästä moraalidynamiikkaan on purettu palasiksi ja rakennettu uudelleen tuottamaan omalaatuisia ja yllättäviä lopputuloksia. Haettu vaikutus on shokeeraava ja yllättävä monellakin tapaa, kuten vaikkapa kohtauksessa, jossa Etsivä1:n kohtaaminen nuoren vandaalinaisen kanssa johtaa varoittamatta Physical Instrument -kyvyn fantasiointiin misogyynisestä väkivallasta. Pelihahmon pään sisällä kuplivat fantasiat, mielihalut ja impulssit - kaikessa synkkyydessään ja ajoittaisessa surkuhupaisuudessaan - tuodaan kykyjärjestelmän avulla pelaajan silmien eteen aggressiivisen alleviivaavasti.

\section{Vatsatotuuksia, vëliseni}

Esimerkkinä kykyjärjestelmän, pelaajan valintojen ja laajempien ideologioiden välisestä suhteesta toimii keskustelu, jonka Etsivä1 käy Kestävyys-kykynsä kanssa esitettyään toistuvasti fasistisia ja misogyynisiä näkemyksiä. Kestävyys käynnistää kohtauksen puhuen "vatsatotuuksista, vëliseni", ja kysyy, tietääkö pelaaja, ketkä ovat kaikkien Revacholin ongelmien takana. Neljästä annetusta 


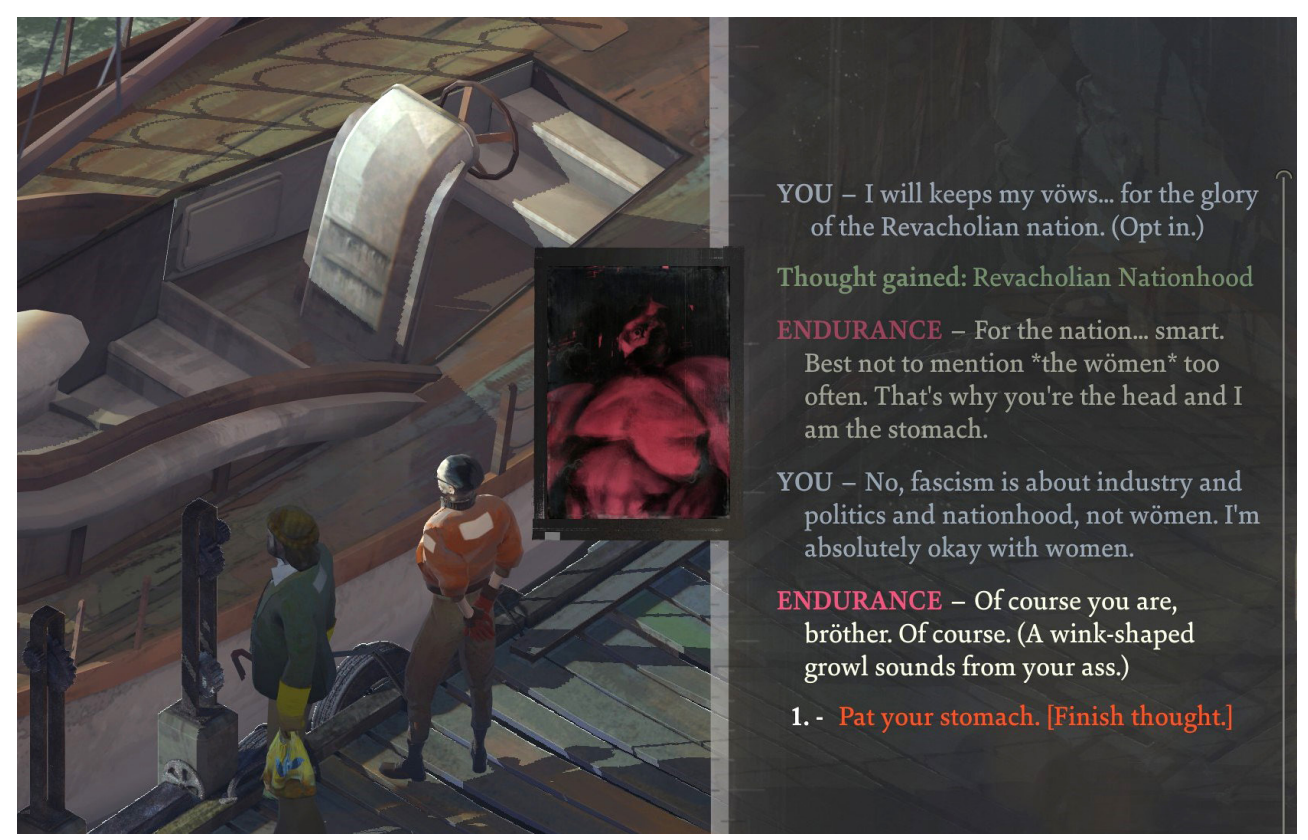

Kuva 2. Etsivä1 öttaa välan [sic].

vaihtoehdosta (ulkomaalaiset, raharikkaat, vasemmistoakateemikot tai liberaalit) kaikki ovat Kestävyyden mukaan oikein, mutta todelliseksi syypääksi tämä paljastaa kuitenkin naiset, jotka eivät tiedä paikkaansa. Tämä, peli ehdottaa, on fasismin perimmäinen ydin. Pelaaja voi ehdottaa, että puhuttaisiin traditionalismista, koska fasismi kuulostaa pahalta, ja Kestävyyskin myöntää, että on fiksua puhua Revacholin kansallisvaltion kunniasta ja jättää naisista puhuminen vähemmälle. Mikäli pelaaja yrittää vakuutella kiinnostuksensa fasismiin kumpuavan tuotantotaloudesta, politiikasta ja kansallisuusaatteesta eikä naisten asemasta, Kestävyys vain leikkii mukana ja iskee silmää (kuva 2).

Kohtauksen avulla peli sitoo Etsivä1:n pelissä esittämät ajatukset osaksi fasismin ideologista raamistoa. Omalla pelikerrallani kohtausta edelsi hahmoni päätös olla pyytämättä Wild Pines -suuryhtiön naispuoliselta edustajalta rahalahjoitusta, koska miesetsiväni anomassa rahaa naiselta järkytti liikaa hahmoni omaksumia käsityksiä sukupuolten valtatasapainosta. Näin peli samanaikaisesti sekä rakentaa merkityksiä hahmoni toimien ja ajatusten ympärille että leikittelee ideologioiden sisäisillä järjestelmillä. Peli esittää ideologioilla olevan oman sisäisen arvojärjestelmänsä, joka voi erota siitä, mitä ne esittävät ulos päin.

Näkemys resonoi sen kanssa, mitä Corey Robin (2018) on kirjoittanut reaktionäärisistä ideologioista yleisesti: että niissä on pohjimmiltaan kyse etuoikeuden - kuvitellun tai todellisen - puolustamisesta ja/tai palauttamisesta. Samassa hengessä Kate Manne $(2018,13)$ on kirjoittanut, että misogynian ei pidä ymmärtää olevan "vain" vihamielisyyttä naisia kohtaan, vaan että kyseessä on toimenpideohjelma sukupuolittuneen valtajärjestelmän ylläpitämiseksi. Disco Elysium tekee samanlaisen argumentin ehdottamalla, että pelihahmon viljelemä misogynia ei ole irrallista, vaan että sen taustalla toimii suurempi ideologinen logiikka. Samalla fasismi näyttäytyy pelissä sen kannattajien kautta lähinnä säälittävältä, eikä pelistä löydy populaarikulttuurille tavanomaista tyyliteltyä ja esteettistä fasismikuvausta (ks. Kallioniemi \& Kärki 2019). Omaksuttuaan fasistisen aatteen alkaa pelaaja kärsiä moraalivahinkoa 
aina puhuessaan nationalismista. Toisin sanoen fasistisen aatteen epäonnistuminen on pelissä niin syvää, että pelaajan on mahdollista "kuolla" moraalin puutteeseen puhumalla aatteensa kulmakiviajatuksesta, kansallisvaltiosta.

Vastaavassa kohtauksessa kommunismin kohdalla on ajavana kykynä älyn alle sijoittuva Retoriikka. Se kertoo aatteen olevan epäonnistumista:

Viheliäistä epäonnistumista. Täydellistä, peruuttamatonta häviötä kaikilla rintamilla! Ehdottoman lannistettu, lyöty, muilutettu ja päälle kustu - kunnes *sinä* saavuit paikalle! *Sinä* tulet kääntämään maailman työläisten onnen. Sinä yksin, vastassasi jokainen elävä ihminen; kahdeksan sataa biljoonaa réalia *uskomattoman* hyvin organisoidun hallitsevan luokan käsissä; taivaisiin kurkottavia kortteleita täynnä pankkiireita kuiskimassa pääministerien korviin; kansakuntien miljoonapäiset armeijat ja oman äitisi rakkaus! Sinä - vastassasi atomi, lumous ja kiertokulku. Missä koko maailma epäonnistui - materia kieltäytyi taipumasta ihmisen tahtoon; ihmistahto epäonnistui nousemaan sängystä ja sitomaan kengännauhansa - sinä yksin, ainoana, tulet jälleenrakentamaan työväenluokan unelmat.

Sarkasmia tihkuva kuvaus ilkkuu ajatukselle, että pelaaja voisi onnistua jossain, mikä on koko historiansa ollut tuomittu epäonnistumiseen. Kommunismi näyttäytyy idealistisena haihatteluna vastassaan todellisuuden painolasti - kirjaimellisesti, koska pelin käyttämä rahayksikkö on nimeltään réal. Kohtauksen päätteeksi Retoriikka huikkaa laittavansa tulituskomppaniat valmiiksi. "Ei voi valmistaa munakasta rikkomatta muutamaa miljoonaa kananmunaa", Retoriikka toteaa epäröivälle pelaajalle. Kommunismissa elää historian syklinen vääjäämättömyys. Samalla peli sitoo pelaajan esittämät näkemykset työväen oikeuksista ja kapitalismin sortorakenteista suurempaan historialliseen epäonnistumisen jatkumoon.

Robert Kurvitz on ilmaissut pääasiallinen poliittisen koulutuksensa juontavan virolaisesta punkista (Nelson 2019). Tutkimuksessaan virolaisten punkkarien arvomaailmasta Joonas Vangonen (2017) on selvittänyt, että punk symbolisoi heille ennen kaikkea ympäröivän maailman negaatiota. Tämä negaation ajatus hallitsee Disco Elysiumin suhtautumista ideologioihin. Yhtäältä ne kaikki ansaitsevat tulla pilkatuksi ja perusolettamuksiltaan horjutetuksi. Toisaalta moralismin ideologian kautta peli kuitenkin argumentoi, ettei ideologiattomuuskaan ole mahdollista. Konfliktista pois jääminen on ideologinen päätös itsessään. Kaikki epäonnistumiset eivät ole samanarvoisia.

Pelin huumori mahdollistaa suorapuheisuuden, jolla se leikkaa läpi ideologioiden ulkokuoresta ja paljastaa niiden sisäiset rakenteet. Tätä huumorin funktiota on korostanut muun muassa Anu Korhonen: huumori on aina vallankäyttöä ja sen avulla on ollut mahdollista esittää näkemyksiä ja tulkintoja, jotka vakavamielisemmin ilmaistuna olisivat vastaavissa kulttuurisissa tilanteissa sosiaalisesti mahdottomia (Korhonen 2013, 10-11; ks. myös Eagleton 2019, 136-140). Pelissä huumorin kohteena on lähes aina pelihahmo itse ja hänen omaksumansa aatteet. Kuten hahmo voi sen itse ilmaista: "Olen turpea vanha juoppo pulisongeissa ja diskohousuissa. Jos minulla ei ole vitsiä hihassani se olen minä itse." Pelin maailma kieltäytyy lähes systemaattisesti antamasta myöten pelihahmon esittämille käsityksille sen perusluonteesta.

Selkeimmin tätä edustaa pelaajan pari Kim Kitsuragi, joka kylmäpäisenä ja asiallisena kieltäytyy myötäilemästä pelaajan pahimpia päähänpinttymiä ja nuhtelee tätä toistuvasti tämän ylilyönneistä. Pelissä on lukuisia haasteita, joissa sekä onnistuminen että epäonnistuminen johtavat epäonnistumiseen eronaan vain kokoluokka. Etsivä2 ei kykene pelin alkupuolella vakuuttamaan Kim Kitsuragia, että murhan taustalla on yliluonnollisia voimia, vaikka peli 
hänelle mahdollisuuden suokin. Onnistuminen haasteessa merkitsee vain, että Kitsuragi tulkitsee yrityksen myötämielisemmin, nähden sen merkkinä protagonistin syyllisyydentunnosta paikallaan junnaavasta tutkinnasta.

Huumorin voi nähdä osaksi pelin moraalijärjestelmää. Mitä villimmin ja absurdimmin pelaaja pelissä käyttäytyy, sitä varmemmin hän voi olettaa joutuvansa pelin pilkan kohteeksi. Niinpä Disco Elysium kutsuu pelaajaa pohtimaan suhdettaan pelihahmoonsa. Juulin $(2013,91-96)$ mukaan tragedian toteuttaminen peleissä on historiallisesti ollut haastavaa, koska pelit sitouttavat yhteen protagonistin ja pelaajan onnistumiset. Disco Elysium kyseenalaistaa pelaajan ja hänen pelihahmonsa klassisen suhteen, jossa pelaajan pyrkimys on saattaa pelihahmo kohti onnistumista (Lankoski 2011, 296-298). Peli kysyy, saako pelaaja enemmän mielihyvää pelihahmon onnistumisesta vaiko siitä, että luo tästä erään kriitikon sanoin täydellisen "roskakatastrofin" ja nauttii päähenkilöön kohdistuvasta pilkasta (Marshall 2019).

\section{Pahat apinat suurella pallolla - Disco Elysiumin maailmankuva}

Antamissaan haastatteluissa Robert Kurvitz on toistuvasti korostanut maailmanrakennuksen merkitystä Disco Elysiumin tuotannossa. Maailma on työstetty pohjaten roolipelisysteemiin, jota Kurvitz on kehittänyt vuosikymmeniä ja johon sijoittuu myös hänen kirjoittamansa vironkielinen romaani Püha ja õudne lõhn (Viro 2013, engl. Sacred and Terrible Air). Pelin tuotantofilosofian ensimmäiseksi periaatteeksi on listattu:

Me teemme yhden järjestelmän, yhden maailman - ja se on siinä. Kaikki sisältyy tähän yhteen rakennelmaan. Kaikki kyvykkyytemme systemaattiseen ajatteluun, kaikki tietomme historiasta. [...] Teemme maailmasta niin valmiin ja totaalisen kuin pystymme. Ja sitten olemme valmiit. Pistämme sen pakettiin ja lähetämme maailmaan, Uuden Testamentin tavoin (Kurvitz 2016).

Totaalijärjestelmän ajatus näkyy pelissä selkeästi. Peli sijoittuu ajallisesti noin viikon mittaiseen periodiin Revacholin kaupungin yhdessä pienessä kaupunginosassa, Martinaisen telakka-alueella. Alue on rajattu, mutta syvä, kuin ikkuna pelin taustalla toimivaan laajempaan maailmaan. Tätä maailmaa hallitsee pelin totaalijärjestelmästä kumpuava holistinen näkemys, jossa se on nähtävissä yhtenäisten periaatteiden kokonaiseksi sitomana. Kun Wild Pines -yhtiön edustaja puhuu "infrakulttuurin" 2 mahdottomuudesta, koska mikä tahansa pyrkimys "suprakulttuurin" ulkopuolelle tulee väistämättä sen osaksi, puhuu hän pohjimmiltaan maailman jakamattomuudesta. Yksi näkemys pelin maailmankuvaan onkin, ettei se sisällä lukuisia kilpailevia ideologisia järjestelmiä, vaan että maailmaa hallitsee yksi ideologinen järjestelmä, jonka osatekijöitä yksittäiset ideologiat ovat.

Ensimmäinen kohtaaminen tämän maailmankuvan kanssa voi tapahtua jo pelin aloituskohtauksessa ennen pelihahmon virkoamista tyhjyydestä. Pelin ensimmäinen dialogi käydään pelaajan, hänen liskoaivojensa ja hänen limbisen järjestelmänsä välillä. Pelaaja voi tiedustella jälkimmäiseltä, mikä häntä odottaa valvemaailmassa. Limbinen järjestelmä vastaa: "Se on oikeastaan vain joukko pahoja apinoita tappelemassa keskenään suurella pallolla." Päästäkseen etenemään pelaajan täytyy kysyä limbisiltä aivoilta lisäkuvausta kamppailusta, mihin tämä vastaa: "Kilpailua resursseista? Vain tyhmä kuvaus, jonka nappasit jostain. Se, mitä haluat muistaa, on tämä: sinun täytyy
2 "Infrakulttuuri" on pelin termi vastakulttuurille. Sen vastakohta on valtakulttuuri, eli "suprakulttuuri". 
lyödä muita pahoja apinoita naamaan tai häviät." Limbisen järjestelmän tarjoamassa maailmankuvassa ideologiat ja niiden materialistiset perusteet, eli kamppailu resursseista, ovat vain hienomman kuuloista kattausta jonkin perinpohjaisemman ylle; suuremman ja groteskimman kilpailuvietin, jota "apinat" pakonomaisesti tottelevat.

Etsivä2 kävi tämän keskustelun ennen heräämistään, kun taas Etsivä1 ei. Täten kuva maailmasta joukkona pahoja apinoita tappelemassa suurella pallolla nousi toistuvasti Etsivä2:n maailmankuvassa, kun taas Etsivä1:lle vastaavaa ei käynyt. Kun hahmoni vajosi hetkeksi tajuttomuuteen pelin alkupuolella, kysyi limbinen järjestelmä Etsivä2:lta, josko pahat apinat olivat alkaneet huutaa vielä. Vastaavaa keskustelua ei Etsivä1 käynyt. Samoin myöhemmin pelissä keskustellessaan maailman perusluonteesta Wild Pines -yhtiön edustajan kanssa Etsivä2 saattoi kysyä, mikäli kommunistista vallankumousta ja sen kukistamista olisi mahdollista kuvailla joukkona apinoita tappelemassa.

Krijn Thjis on kirjoittanut historian suurista kertomuksista ja niiden siirtymisestä pienempiin, paikallisempiin konteksteihin. Hän on hahmottanut master-copy-dynamiikan, jossa suuret kertomukset ovat historiallisen tulkinnan master-nauhoja, joiden sisältö ja muoto on mahdollista kopioida eteenpäin ja täten tuottaa uudelleen yhä erilaisissa konteksteissa. (Thjis 2008, 68-69.) Disco Elysium simuloi tätä kertomusten siirtymistä. Limbinen järjestelmä esittää suuren kertomuksen pelin maailmasta ja tämän jälkeen kyseinen kertomus tulee toistetuksi ja paikoin myös muokatuksi ja debatoiduksi pelin kuluessa. Se esitetään pelaajalle, mutta tämän ei ole pakko hyväksyä sitä.

Pelin selkein symboli toistuvalle maailmankuvalle on disko. Se on vuosikymmenten takainen musiikkikulttuuri, jonka kulta-aikaan päähahmo takertuu. Hän on elävä reliikki, jaloissaan käärmeennahkakengät ja yllään vuosikymmeniä ajastaan irrotettu bleiseri. Kasvoillaan pelihahmo kantaa Ilmettä, jonka alkuperää hän voi Ensyklopedia-kyvyllä pelin alussa pyrkiä selvittämään tuijottaessaan peilistä hirviömäiseksi kuvailtuja kasvojaan, joita ei tunnista (kuva 3).
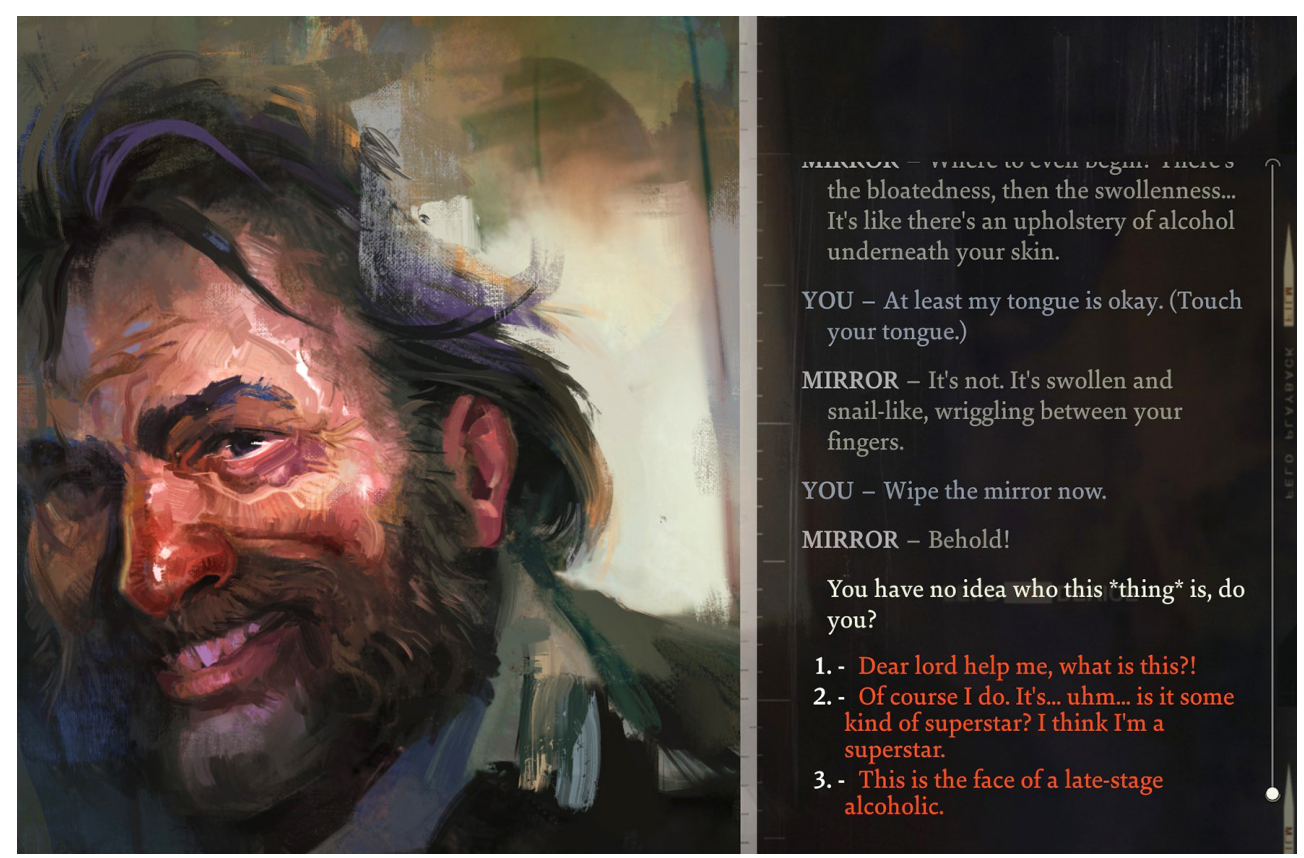

Kuva 3. The Expression. 
Onnistuneen heiton ansiosta Ensyklopedia valaisee Etsivä2:a:

Tarpeeksi aikaa oli kulunut epäonnistuneesta Vallankumouksesta, että pienen hetken ajan vapaa markkinatalous oli tuntunut lajimme lopulliselta, kiistattomalta elintavalta. [...] Asiat olivat hyvin. Kaikki sujui kuin tanssi. Ihmiset tekivät kullan-ja-shampanjan värisiä sisätiloja ja julkisivuja ajan hengessä ja kutsuivat sitä Uudeksi Tyyliksi. Mutta, vielä tärkeämmin - disko tapahtui. [...] Se tarkoitti vain yhtä asiaa: Guillaume Le Million! [...] Diskomusiikin välkehtivästä kiepunnasta [...] Guillaumen vaaleat hiukset ilmaantuivat ruudulle. Hän lauloi jotain hevonpaskaa. Ja sitten hän teki *Ilmeen*.

Disko nousee pelissä kadonneen kulta-ajan nostalgiseksi symboliksi, mutta sen kultaisuus näyttäytyy arveluttavana. Disko musiikkityylinä oli vain jotain "hevonpaskaa", mutta kimalle supertähden ympärillä ja ilme tämän naamalla oli sen kulttuurisen ilmiön ytimessä. Diskon kautta kapitalismi oli yrittänyt esiintyä totaalisena maailmankuvana, suurkertomuksena, mutta aika oli todistanut kuvan valheeksi ja kääntänyt sen itseään vastaan. Laittamalla Guillaume Le Millionin ajatuskabinettiinsa pelaaja voi selvittää tähden kuolleen kiertueella autoeroottiseen asphyksiaatioon hittilaulu "Wonderlandin" jumittaessa taustalla. Peli alleviivaa: "Ja kyllä, voit ottaa tämän metaforana Revacholille 30-luvulla." Unissaan pelihahmo näkee itsensä pihapuuhun diskopallon alle hirtettynä vainajana. Disko petettyine lupauksineen on sitonut sisäänsä ajatuksen toivosta ja kiskonut sen tulevaisuudesta kohti historiaa.

Diskon lupaus historian päättymisestä luo paralleeleja Francis Fukuyaman vastaavaan väitteeseen Neuvostoliiton sorruttua. Fukuyamalle historia oli ideologioiden kamppailua, joka oli tullut nyt tiensä päähän (Fukuyama [1992] 2006). Paralleelia alleviivaa Etsivä2:n Wild Pines -edustajan kanssa käymä keskustelu Revacholin kaupunkiin liittyvästä lupauksesta, jonka mukaan historia tulisi siellä ratkaistuksi. Revachol olisi paikka, jossa "aikamme kauheimmat kysymykset tulevat vastatuiksi - jännitteet ovat korkeimmillaan, jakolinjat syvimmillään". Tämäkin lupaus epäonnistui: vallankumous tuli ja meni, vain suuret kysymykset jäivät elämään. Wild Pines -edustaja toteaa, ettei nykyhetki ole tärkeä: "Me synnyimme, kun tomu oli jo asettunut, tuhannesosasekunnin liian myöhään." Historian tärkeät hetket oli käyty jo läpi eikä tulevaisuudella ollut tarjottavaa.

\section{"Menneisyys on tulevaisuus - mutta tulevaisuus on kuollut"}

Tuijotettuaan kasvojaan hotellihuoneensa peilissä voi pelihahmo yrittää poistaa diskon Ilmettä kasvoiltaan Sähkökemia-kyvyllä. Haaste on niin suunnaton, että siinä onnistuminen pelin alkupuolella vaatii kriittisen onnistumisen. Pelihahmo on menneisyytensä vanki, kyvytön päästämään irti diskon lupauksesta. Sama koskee Revacholin maailmaa, jossa epäonnistuneen vallankumouksen varjo peittää alleen mahdollisuuden edes ajatella tulevaa.

Pelin loppuratkaisussa (SPOILER) selviää, ettei murhalla ollut mitään tekemistä nousevan lakon tai siihen liittyvien jännitteiden kanssa. Murhaaja oli saarelle telakka-alueen ulkopuolelle majoittunut kommunistisotilas, joka jatkoi vuosikymmenten takaista vallankumoussotaa. Siinä missä päähenkilö on nostalgisesti lukittuna diskoon lupausten ja toivon aikana, niin myös pelin lopullinen antagonisti - ja hänen myötään koko pelin kuvaama telakka-alue - oli vangittuna menneisyyteen, tuomittuna elämään kauan sitten epäonnistuneen vallankumouksen ideologista taistoa vailla toivoa voitosta. 
Michael Freedenin (2009a, 4) mukaan ideologiat puolustautuvat epäonnistumissyytöksiä vastaan siirtämällä visioitaan tulevaisuuteen. Tällöin niiden epäonnistuminen ei määrity nykyisyydessä, vaan siinä, missä määrin tämä tulevaisuuden visio resonoi ideologian kohdeyleisössä. Disco Elysiumissa ideologiat eivät kuitenkaan kykene tarttumaan tulevaisuuteen ja niinpä niistä tulee vitsien kohteita. Niiden lupaukset suuntaavat menneisyyteen, jossa niiden tyhjyys on paljastunut.

Samalla pelin ideologisten konfliktien kiertokulku sitoutuu aikaan, joka itsessään on päättymässä. Pelin maailman ainoa selkeästi fantastinen elementti on Kalpeus (The Pale) - maailman reunamia peittävä sumumainen massa, jonka sisällä materia, fysiikan lait ja jopa aika lakkaavat toimimasta. Pelin myötä pelaajalle voi selvitä, että Kalpeus on leviämässä halki pelin tuhoon tuomitun maailman ja tulee lopulta syömään sisäänsä sen koko pinta-alan (Trahan 2020). "Disco Elysium" on nimi, jonka pelaaja voi antaa neljän nuoren vanhaan kirkkoon perustamalle yökerholle. Sen keskellä on täydellisen hiljaisuuden piste - reikä maailmassa, jonka peli implikoi olevan merkki Kalpeuden saapumisesta Revacholiin. Yksi nuorista kommentoi nimeä: "Menneisyys on tulevaisuus - mutta tulevaisuus on kuollut!"

Keskusteluistaan Kalpeuden läpi ajaneen rekkakuskin kanssa pelaaja voi oppia Kalpeuden syövän sille altistuneelta ihmiseltä kyvyn erotella aikaa. Menneisyys ja nykyisyys muodostuvat yhdenvertaisiksi. Kalpeuden aikaluonne tuottaa fantastisen metaforan Revacholia hallitsevalle aikakäsitykselle, jossa menneisyys epäonnistumisineen syö sisäänsä nykyisyyden ja kuihduttaa mahdollisuuden tulevaisuudesta. Telakka-alueella vanhukset pelaavat petankkia kraatterissa, jonka on jättänyt jälkeensä vallankumouksen kukistanut tykistötuli. Halki kaupunkikorttelin voi pelaaja löytää seinämiin jääneitä luodinreikiä ja asekätköjä. Sodan murjomien asuntojen asukkaat on kuvattu historian raunioissa kuokkivina vieraina. Historia epäonnistumisineen kummittelee kaupungin yllä eikä jätä sitä rauhaan.

\section{Lopuksi: Epäonnistumisen ideologia}

Disco Elysium on peli epäonnistumisesta. Samalla se on simulaatio 2010-luvun lopun poliittiseen hetkeen johtaneista historiallisista ja ideologisista linjastoista. Tämä on sen manifestisuuden perusydin. Se kanavoi hetkeä, jossa uusliberalismin muodossa valtaan noussut paradigma on esittänyt heikkoutensa ja avannut kentän vanhojen, jo epäonnistuneiden ideologioiden nousulle (ks. Brown 2019; myös Harvey 2005). Tämä näkemys nykyhetkestä on se historiallinen suuri kertomus, jonka rakenteen peli on kopioinut sisäänsä ja jonka pohjalta se pelikokemuksensa luo. Ajatusta heijasteli myös Time-lehti kuvaillessaan sitä videopeliksi, "joka on juurtunut syvälle menneeseen, mutta katsoo kuitenkin tulevaan. Se on sellainen videopeli, joka voi syntyä vain vuosikymmenen vaihteessa, siinä erityisessä hetkessä, kun jotain päättyy ja jotain uutta puolestaan syntyy" (Gault 2019).

Disco Elysium esittäytyy siirtymäajan mediatuotteena. Se rakentaa fantastisen ekstrapoloidun kuvaelman nykyhetkestä ja täten pyrkii paljastamaan sitä hallitsevat lainalaisuudet. Aivan kuten pelissä Revachol on paikka, jonka lupauksena oli simuloida pelin ideologioiden suurten kysymysten kamppailu, niin myös peli itsessään on rakentunut simuloimaan nykyhetkeen johtaneen historian hallitsevia ideologisia konflikteja maailmassa, joka on tuotettu systemaattisesti tätä tarkoitusta varten. Pelin maailma esittäytyy todenpuhuvana 
hypertodellisuutena, jossa ideologioiden perimmäiset totuudet ja niitä hallitsevat impulssit esittäytyvät raaimmassa muodossaan.

Michael Freeden on esittänyt, että epäonnistuminen tulisi nähdä kaiken poliittisen ajattelun oletuslopputuloksena. Hän ei tarkoita tällä sanoa, että poliittinen ajattelu olisi turhaa tai viallista, vaan että normalisoimalla epäonnistuminen hävitetään binäärinen ajatus, että ideologiat joko onnistuvat tai epäonnistuvat totaalisesti. (Freeden 2009b, 144-145.) Samoin Disco Elysium esittää, että epäonnistuminen tulisi nähdä ihmisyyden oletusarvona. Pelin pelaaminen epäonnistumista vältellen on tylsää ja pitkälti mahdotonta. Peli kannustaa ottamaan riskejä ja seuraamaan mitä omituisimpia ajatuskulkuja niiden loppuun asti. Se reflektoi tätä pelaamisen ja elämän yhteen kietoutumaa pelistä löytyvän nopantekijän kautta. Nopantekijä filosofoi: "Aina kun heität noppaa, jotain katoaa. Joku vaihtoehtoinen loppu, tai täysin erilainen maailma." Päätös olla heittämättä kuitenkin tarkoittaa kaikkien mahdollisuuksien katoamista. Elämä ilman epäonnistumista ei ole todellisuutta.

\section{Lähteet}

Aarseth, Espen (2007) Doors and Perception: Fiction vs. Simulation in Games. Intermediality: History and Theory of the Arts, Literature and Technologies vol. 9, 35-44.

Adams, Jon (2019) Why We Play Role-Playing Games. Teoksessa Sascha Pöhlmann (toim.) Playing the Field: Video Games and American Studies. Oldenbourg: De Gruyter, 185-194.

Arguello, Diego (2020) Why I Love Failing in Disco Elysium. PC Gamer. Saatavilla: <https:// www.pcgamer.com/why-i-love-failing-in-disco-elysium/> (linkki tarkistettu 5.5.2020).

Arjoranta, Jonne (2015) Johdanto. Teoksessa Jonne Arjoranta (toim.) Lähipeluu: Luentoja digitaalisista peleistä. Jyväskylä: Jyväskylän yliopisto, 5-8.

Bogost, Ian (2007) Persuasive Games: The Expressive Power of Video Games. Cambridge: The MIT Press.

Bos, Daniel (2018) Answering the Call of Duty: Everyday Encounters with the Popular Geopolitics of Military-Themed Videogames. Political Geography vol. 63, 54-64.

Brown, Wendy (2019) In the Ruins of Neoliberalism: The Rise of Antidemocratic Politics in the West. New York: Columbia University Press.

Chalk, Andy (2019) Disco Elysium is a "Colossal" Game That Can Take 90 Hours to Finish. PC Gamer. Saatavilla: <https://www.pcgamer.com/disco-elysium-is-a-colossal-game-that-cantake-90-hours-to-finish/> (linkki tarkistettu 5.5.2020).

Cox, Matt (2018) "We Accommodate for Every Stupid Thing That You Wanna Do" - How Disco Elysium Makes Detective Games Work. Rock Paper Shotgun. Saatavilla: <https://www. rockpapershotgun.com/2018/05/29/disco-elysium-rpg-details/> (linkki tarkistettu 5.5.2020).

Cresswell, Tim (1996) In Place/Out of Place: Geography, Ideology, and Transgression. Minneapolis: University of Minnesota Press.

Eagleton, Terry (2019) Humour. New Haven: Yale University Press.

Foong, LM (2020) Disco Elysium is an Enchanting Lesson on Failure. Decon Recon. Saatavilla: $<$ https://deconrecon.asia/feature/disco-elysium-is-an-enchanting-lesson-on-failure/> (linkki tarkistettu 16.10.2020).

Frasca, Gonzalo (2003) Simulation versus Narrative. Teoksessa Mark J.P. Wolf \& Bernard Perron (toim.) The Video Game Theory Reader. New York: Routledge, 221-235.

Freeden, Michael (2009a) Editorial: What Fails in Ideologies? Journal of Political Ideologies vol. 14(1), 1-9.

Freeden, Michael (2009b) Failures of Political Thinking. Political Studies vol. 57, 141-164.

Freeden, Michael (2013) The Political Theory of Political Thinking: The Anatomy of a Practice. Oxford: Oxford University Press. 
Freeden, Michael (2019) Mitä on ideologia? Tampere: niin \& näin.

Fukuyama, Francis (2006 [1992]) The End of History and the Last Man. New York: Free Press.

Gault, Matthew (2019) The 10 Best Video Games of the 2010s. TIME. Saatavilla: <https://time. com/5752663/best-video-games-2010s-decade/> (linkki tarkistettu 5.5.2020).

Geertz, Clifford (1973) The Interpretation of Cultures. Selected Essays by Clifford Geertz. New York: Basic Books.

Gray, Kishonna L.; Voorhees, Gerald \& Vossen, Emma (toim.) (2018) Feminism in Play. Cham: Springer International Publishing AG.

Hallila, Mika (2006) Metafiktion käsite: Teoreettinen, kontekstuaalinen ja historiallinen tutkimus. Joensuu: Joensuun yliopisto.

Harvey, David (2005) A Brief History of Neoliberalism. New York: Oxford University Press.

Heliö, Satu (2004) Role-Playing: A Narrative Experience and a Mindset. Teoksessa Markus Montola \& Jaakko Stenros (toim.) Beyond Role and Play: Tools, Toys, and Theory for Harnessing the Imagination. Helsinki: Ropecon ry., 65-74.

Jackson, Gita (2019) Disco Elysium Developers Shout Out Marx and Engels in Game Awards Victory Speech. Kotaku. Saatavilla: <https://kotaku.com/1840436684> (linkki tarkistettu 5.5.2020).

Janecek, G. J. (2012) ZAUM. Teoksessa Roland Greene, Stephen Curshman, Clare Cavanagh, Jahan Ramazani \& Paul Rouzer (toim.) The Princeton Encyclopedia of Poetry and Poetics. Princeton: Princeton University Press, 1552.

Juul, Jesper (2013) The Art of Failure: An Essay on the Pain of Playing Video Games. Cambridge, Lontoo: The MIT Press.

Kallioniemi, Kari \& Kärki, Kimi (2019) Populaarikulttuurin estetisoima ja normalisoima natsismi. Lähikuva 1/2019, 67-71. Saatavilla: <https://doi.org/10.23994/lk.80167>.

Karhulahti, Veli-Matti (2015) Adventures of Ludom: A Videogame Geneontology. Turku: Turun yliopiston julkaisuja - Annales Universitatis Turkuensis.

Korhonen, Anu (2013) Kiusan henki: Sukupuoli ja huumori uuden ajan alussa. Helsinki: Atena.

Kurvitz, Robert (2016) The Design Ethos of Our Role Playing System. Saatavilla: <https://zaumstudio.com/2016/09/30/design-ethos-role-playing-system/> (linkki tarkistettu 5.5.2020).

Lankoski, Petri (2011) Player Character Engagement in Computer Games. Games and Culture vol. 6(4), 291-311.

Linderoth, Jonas \& Mortensen, Torill Elvira (2015) Dark Play: The Aesthetics of Controversial Playfulness. Teoksessa Torill Elvira Mortensen, Jonas Linderoth \& Ashley ML Brown (toim.) The Dark Side of Game Play: Controversial Issues in Playful Environments. New York: Routledge, 3-14.

Maier, Patricia (2019) Mobility and Choices in Role-Playing Games. Teoksessa Sascha Pöhlmann (toim.) Playing the Field: Video Games and American Studies. Oldenbourg: De Gruyter, 65-77.

Manne, Kate (2018) Down Girl: The Logic of Misogyny. London: Penguin Books.

Marshall, Cass (2019) I Love Being a Trash Disaster in Disco Elysium. Polygon. Saatavilla: $<$ https://www.polygon.com/2019/12/24/21001727/disco-elysium-choices-bad-guy-run> (linkki tarkistettu 5.5.2020).

McCarthy, Caty (2019) How the “Last Living Soviet Video Game Developers" Recruited Chapo Trap House for Disco Elysium. USgamer. Saatavilla: <https://www.usgamer.net/articles/discoelysium-chapo-trap-house-podcast-voice-acting-feature $>$ (linkki tarkistettu 5.5.2020).

McDonald, Tim (2019) Disco Elysium Killed Me in Three Minutes, with a Ceiling Fan. PC Invasion. Saatavilla: $<$ https://www.pcinvasion.com/disco-elysium-killed-me-in-three-minuteswith-a-ceiling-fan/> (linkki tarkistettu 5.5.2020).

Montola, Markus (2012) On the Edge of the Magic Circle: Understanding Role-Playing and Pervasive Games. Tampere: Tampere University Press.

Mortensen, Torill Elvira (2015) Keeping the Balance: Morals at the Dark Side. Teoksessa Torill Elvira Mortensen, Jonas Linderoth \& Ashley ML Brown (toim.) The Dark Side of Game Play: Controversial Issues in Playful Environments. New York: Routledge, 154-170.

Muriel, Daniel \& Crawford, Garry (2018) Video Games as Culture: Considering the Role and Importance of Video Games in Contemporary Society. London: Routledge.

Mähkä, Rami (2016) Basil Falty ja "esitatcherilaisuus" sarjassa Pitkän Jussin majatalo. Lähikuva 1/2016, 26-47. Saatavilla: <https://doi.org/10.23994/lk.58359>. 
Mäyrä, Frans (2008) An Introduction to Game Studies: Games in Culture. Los Angeles, Lontoo, New Delhi, Singapore: SAGE Publications.

Nelson, Samantha (2019) Why the Creator of Disco Elysium Hasn't Read the Reviews, and What's Next for the IP. The Escapist. Saatavilla: <https://www.escapistmagazine.com/v2/ why-the-creator-of-disco-elysium-hasnt-read-the-reviews-and-whats-next-for-the-ip/> (linkki tarkistettu 5.5.2020).

Puchner, Martin (2006) Poetry of the Revolution. Marx, Manifestos, and the Avant-Gardes. Princeton and Oxford: Princeton University Press.

Robin, Corey (2018) The Reactionary Mind: Conservatism from Edmund Burke to Donald Trump. Oxford: Oxford University Press.

Ryan, Marie-Laure (2006) Avatars of Story. Minneapolis: University of Minnesota Press.

Sicart, Miguel (2009) The Ethics of Computer Games. Cambridge: The MIT Press.

Street, John; Inthorn, Sanna \& Scott, Martin (2013) From Entertainment to Citizenship: Politics and Popular Culture. Manchester: Manchester University Press.

Taylor, Nicholas \& Voorhees, Gerald (toim.) (2018) Masculinities in Play. Cham: Springer International Publishing AG.

Thjis, Krijn (2008) The Metaphor of the Master: "Narrative Hierarchy" in National Historical Cultures of Europe. Teoksessa Stefan Berger \& Chris Lorenz (toim.) The Contested Nation: Ethnicity, Class, Religion, and Gender in National Histories. Basingstoke: Palgrave Macmillan, 60-74.

Trahan, Philip (2020) The World of Disco Elysium Explained. Game Rant. Saatavilla: <https:// gamerant.com/disco-elysium-world-explained/> (linkki tarkistettu 5.5.2020).

Vangonen, Joonas (2017) Research Project: Estonian punk (1985-1995). Pop History. Saatavilla: $<$ https://pophistory.hypotheses.org/2434> (linkki tarkistettu 5.5.2020).

White, William J.; Arjoranta, Jonne; Hitchens, Michael; Peterson, Jon; Torner, Evan \& Walton, Jonathan (2018) Tabletop Role-Playing Games. Teoksessa José P. Zagal \& S. Deterding (toim.) Role-Playing Game Studies: Transmedia Foundations. New York: Routledge, 65-86.

ZA/UM (2016) Announcing No Truce With the Furies. Saatavilla: <https://zaumstudio. com/2016/06/09/233/> (linkki tarkistettu 5.5.2020).

ZA/UM (2020) Disco Elysium by ZA/UM. Saatavilla: <https://zaumstudio.com/> (linkki tarkistettu 15.10.2020). 